\title{
Dysfunction of atrial and B-type natriuretic peptides in congenital univentricular defects
}

\author{
Lena S. Sun, MD, ${ }^{a, b}$ Carmen Dominguez, MD, ${ }^{a}$ Navin A. Mallavaram, MD, and Jan M. Quaegebeur, MD, $\mathrm{PhD}^{\mathrm{c}}$
}

Objective: To examine whether children with univentricular defects have intrinsic dysfunction in the natriuretic peptide system.

Methods: We compared plasma levels of the fluid-regulating hormone vasopressin (antidiuretic hormone), aldosterone, atrial natriuretic peptide, and brain natriuretic peptide in children with congenital univentricular and biventricular defects. We enrolled 27 patients with univentricular defects and 27 patients with biventricular cardiac defects. Children who underwent Fontan and Glenn procedures were considered as patients with univentricular cardiac defects; children who underwent repair of tetralogy of Fallot or subaortic stenosis were considered as controls with biventricular defects.

Results: Preoperative plasma atrial natriuretic peptide, brain natriuretic peptide, antidiuretic hormone, and aldosterone were comparable in both groups. Although plasma cyclic guanosine monophosphate levels were comparable between groups, there was a significant correlation between molar concentrations of plasma cyclic guanosine monophosphate and plasma atrial natriuretic peptide $(r=0.42)$ and brain natriuretic peptide $(r=0.44)$ in the biventricular group, but not in the univentricular group ( $r=0.19$ for atrial natriuretic peptide; $r=0.13$ for brain natriuretic peptide). All patients had a significant postoperative increase in plasma antidiuretic hormone. A significant postoperative increase in plasma brain natriuretic peptide was found in the patients with biventricular, but not univentricular, defects. In contrast, a significant increase in plasma aldosterone was observed only in the patients with univentricular defects.

From the Departments of Anesthesiology, Pediatrics, ${ }^{\mathrm{b}}$ and Surgery, ${ }^{\mathrm{c}}$ College of Physicians and Surgeons, Columbia University, New York, NY.

The study was supported in part by a Clinical Trials Pilot Award from ColumbiaPresbyterian Medical Center.

Received for publication June 8, 2004; revisions received Aug 3, 2004; accepted for publication Aug 6, 2004.

Address for reprints: Lena S. Sun, MD, Columbia University, College of Physicians and Surgeons, BH 4-440 North, 630 W 168th St, New York, NY 10032 (Email: Iss4@columbia.edu).

J Thorac Cardiovasc Surg 2005;129: $1104-10$

$0022-5223 / \$ 30.00$

Copyright () 2005 by The American Association for Thoracic Surgery

doi:10.1016/j.jtcvs.2004.08.025
Conclusions: There were distinct differences between univentricular and biventricular groups in their perioperative plasma fluid-regulating hormone responses. Specifically, patients with univentricular defects may have abnormal natriuretic peptide secretion and function. The natriuretic dysfunction may be on the basis of hypoplastic ventricular development.

$\mathrm{T}$ he natriuretic peptide system has 3 natriuretic peptides, and 2 of these natriuretic peptides are cardiac hormones that have been reported to regulate fluid homeostasis. ${ }^{1-4}$ Atrial natriuretic peptide (ANP) is a 28 -amino acid peptide hormone derived from a prohormone synthesized and mostly stored in the atria. It causes diuresis, natriuresis, and vasorelaxation. It inhibits the release and action of the antidiuretic hormone (ADH) vasopressin and the antinatriuretic hormone aldosterone. B-type natriuretic peptide (BNP) is a 32-amino acid peptide hormone secreted in the ventricles that also promotes natriuresis and diuresis and induces vasodilation, with antagonist effects on vasopressin $(\mathrm{ADH})$ and aldosterone. ${ }^{1,3,5}$ The second-messenger pathway for both of these hormones involves a cyclic guanosine monophosphate (cGMP)-dependent pathway mediated through stimulation of the membrane-bound guanylyl cyclase. In addition, ANP may also 
transduce its signal via a cyclic adenosine monophosphatedependent pathway mediated through inhibition of adenylyl cyclase.

Studies in the rat heart indicate that the ventricular content of ANP messenger RNA is high during the fetal period and then gradually diminishes until its rapid disappearance after birth. ${ }^{2}$ The atrial content of ANP messenger RNA is low during the fetal period but increases progressively after birth. Studies of the ontogeny of the ANP hormonal system in the human heart also revealed the appearance of significant quantities of ventricular ANP beginning in the early fetal period that decreased with advancing gestational age. ${ }^{2,4}$ It is not known whether this developmental transition from ventricular to atrial predominance of ANP is disrupted when cardiac malformation occurs during organogenesis, particularly in situations involving underdevelopment of one of the ventricles, such as congenital hypoplastic right or left ventricles. An increase in plasma ANP has been consistently found in patients with congenital cardiac defects, ${ }^{5-8}$ and this suggests that the secretion or release (or both) of the hormone is intact. There is much less information regarding the developmental pattern of BNP gene expression and hormone secretion.

Although plasma natriuretic peptide secretion has been examined in adults and children after cardiac surgery, ${ }^{9-12}$ the precise role of natriuretic hormones in the regulation of fluid balance in the pediatric patient who has had cardiac surgery has not been well studied. No study has specifically examined natriuretic hormone receptor/effector signal transduction in the pediatric patient with univentricular cardiac defects. Children who undergo palliative or reparative procedures for univentricular defects often have postoperative complications related to the regulation of fluid homeostasis. ${ }^{13,14}$ Fontan and Glenn procedures are frequently performed in patients with single ventricles. ${ }^{15-18}$ Pleural effusion, pericardial effusion, and fluid retention often complicate the postoperative course of these patients. ${ }^{19,20}$ Fontan patients often have increased ANP because of many different factors. Earlier studies have documented that plasma ADH is correlated with fluid retention in the presence of increased ANP in these patients, and this is consistent with a defect in ANP cellular action. ${ }^{19}$ Other investigators have similarly documented increased plasma ADH and ANP in patients having Glenn procedures. ${ }^{20}$ Nevertheless, no study has examined the change in plasma BNP in these patients, nor has any study examined the natriuretic receptor coupling to the guanylyl cyclase enzyme. Tetralogy of Fallot and subaortic stenosis are 2 congenital cardiac defects that are surgically corrected during early infancy. Neither of these lesions involves underdevelopment of the ventricles.

Plasma levels of both ANP and BNP are increased in patients with congestive heart failure. ${ }^{21-24}$ Downregulation
TABLE 1. Patient data

\begin{tabular}{lcc}
\hline Variable & Univentricular & Biventricular \\
\hline Age (mo) & $28.1 \pm 28$ & $22.8 \pm 24.2$ \\
Sex (male/female) & $15 / 12$ & $15 / 12$ \\
Duration of CPB (min) & $135.9 \pm 75$ & $115.8 \pm 49.6$ \\
Duration of crossclamp (min) & $70.4 \pm 46.9$ & $65.6 \pm 23.1$ \\
Lowest temperature $\left({ }^{\circ} \mathrm{C}\right)$ & $25 \pm 5.6$ & $25 \pm 2.6$ \\
\hline
\end{tabular}

$C P B$, Cardiopulmonary bypass.

of ANP receptors coupled to guanylyl cyclase, as evidenced by plateauing plasma levels of cGMP in the presence of increased plasma ANP levels, has been reported in patients with severe congestive heart failure. ${ }^{25}$ Plasma ANP concentrations are increased in patients with cyanotic congenital cardiac defects, even without clinical evidence of failure. ${ }^{26}$ In addition, plasma ANP and BNP levels have been reported to be increased in children with congenital cardiac defects undergoing cardiopulmonary bypass for cardiac surgery. ${ }^{10,27,28}$ In healthy individuals, plasma ANP far exceeds plasma BNP. ${ }^{29}$ In patients with cardiac failure, not only do plasma ANP and BNP both increase, but ventricular secretion of BNP is also greatly stimulated, so that plasma BNP is higher than plasma ANP. ${ }^{30}$

In this study, we studied 2 groups of patients: (1) those with univentricular defects who were undergoing Fontan or Glenn procedures and (2) those with biventricular defects who were undergoing repair of tetralogy of Fallot or subaortic stenosis. We hypothesized that the altered fluid balance that often complicates the postoperative course after Fontan and Glenn procedures may be attributable to dysfunction in the natriuretic peptide hormonal system. The dysfunction could occur at several steps: natriuretic peptide synthesis, storage, release, receptor coupling, and receptor signal transduction could be affected alone or in combination.

\section{Methods}

The study was approved by the institutional review board. Two groups of patients were studied (Table 1):

1. Patients with congenital univentricular cardiac defects: patients undergoing Fontan or bidirectional Glenn shunt operations with congenital hypoplastic right heart defects (tricuspid atresia, single ventricle, Ebstein anomaly, or other congenital cardiac defects associated with hypoplastic right ventricle) or patients who have had the Norwood procedure for hypoplastic left heart syndrome.

2. Control patients with congenital cardiac defects but with 2 ventricular chambers: patients undergoing repair of tetralogy of Fallot or subaortic stenosis.

All patients had general endotracheal tube anesthesia with a standardized anesthetic regimen consisting of fentanyl 25 to 50 $\mu \mathrm{g} / \mathrm{kg}$ and vecuronium $0.2 \mathrm{mg} / \mathrm{kg}$ as the intravenous muscle relaxant for induction; $100 \%$ oxygen was used in all patients. Each 


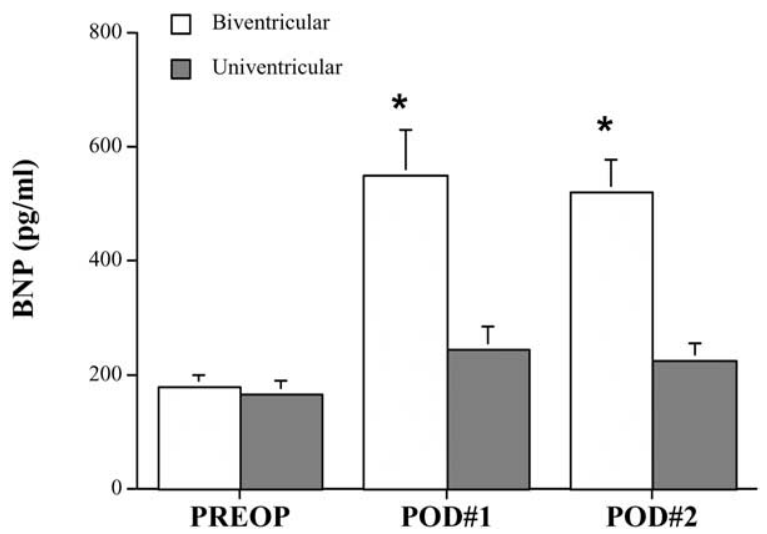

Figure 1. Plasma BNP was comparable before surgery in the univentricular and biventricular patients. A significant increase in plasma BNP was seen during the first 2 postoperative days in the biventricular patients on postoperative day (POD) 1 and POD 2. No change in plasma BNP was evident in the univentricular patients. ${ }^{*} P<.05$ versus before surgery (PREOP).

patient then received fentanyl $100 \mu \mathrm{g} / \mathrm{kg}$ before the initiation of cardiopulmonary bypass. Sodium nitroprusside was used as the vasodilator during cardiopulmonary bypass. If indicated, anesthesia was supplemented with isoflurane and midazolam 0.1 to 0.3 $\mathrm{mg} / \mathrm{kg}$ during and after cardiopulmonary bypass.

Blood samples were collected into chilled tubes containing aprotinin (a peptidase inhibitor) and isobutylmethylxanthine (a phosphodiesterase inhibitor) after the induction of anesthesia, before surgical incision, on postoperative day 1, and on postoperative day 2 and were maintained on ice. Plasma was then separated and stored at $-70^{\circ} \mathrm{C}$. Peptide and cyclic nucleotides were extracted,

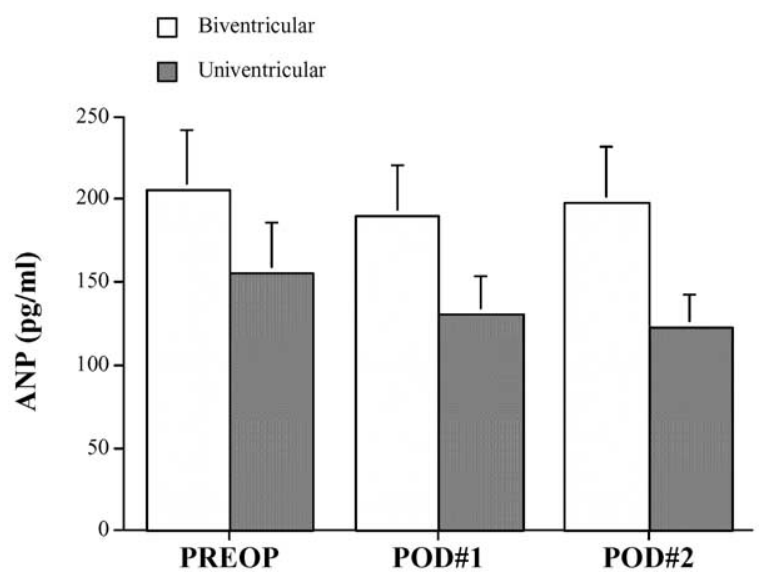

Figure 2. Plasma ANP was comparable between univentricular and biventricular patients ( $n=27$ in each group). No significant change in plasma ANP was observed during the first 48 hours after surgery, on postoperative day (POD) 1, or on POD 2. PREOP, Before surgery.

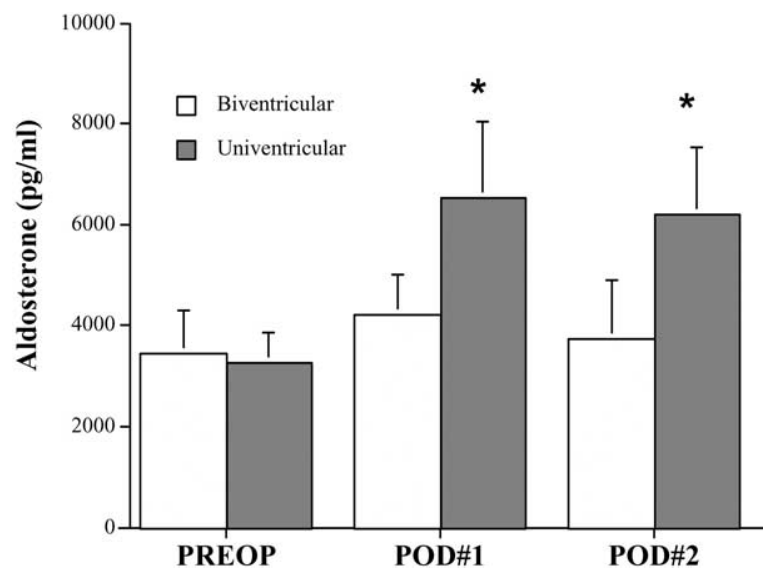

Figure 3. Plasma aldosterone was comparable in both groups. Although biventricular patients showed no change in plasma aldosterone, univentricular patients showed a significant increase in plasma aldosterone on both postoperative day (POD) 1 and POD 2. ${ }^{*} P<.05$ versus before surgery (PREOP).

and ANP, BNP, and cGMP were measured with commercially available radioimmunoassay kits.

One-way analysis of variance was used to determine the change over time of ANP, BNP, and plasma cGMP for each group. Pairwise comparisons were performed between different points and preincision values by the Bonferroni test for ANP, BNP, and cGMP within groups. Comparisons between groups were made with nested analysis of variance. Correlation of ANP and/or BNP with plasma cGMP was assessed by least-squares linear regression.

\section{Results}

The plasma natriuretic peptides ANP and BNP were comparable before surgery in children with univentricular $(\mathrm{n}=$ 27; ANP, $156.3 \pm 30 \mathrm{pg} / \mathrm{mL}$; BNP, $167.5 \pm 21.2 \mathrm{pg} / \mathrm{mL}$ ) and biventricular $(\mathrm{n}=27$; ANP, $205.9 \pm 36 \mathrm{pg} / \mathrm{mL}$; BNP, $178.3 \pm 20.7 \mathrm{pg} / \mathrm{mL}$ ) defects. We determined the perioperative pattern of plasma ANP and BNP to examine the natriuretic peptide response to cardiac surgery in these children. In children with biventricular defects, there was a significant postoperative increase in BNP (Figure 1) and very little change in plasma ANP (Figure 2). In contrast, both plasma ANP (Figure 2) and BNP (Figure 1) remained unchanged during the first 48 hours after the Glenn and Fontan procedures. It is interesting to note that the aldosterone response was robust after surgery in children with univentricular defects but was unremarkable in those with biventricular defects (Figure 3). There was a significant increase in $\mathrm{ADH}$ on postoperative day 1 in children with both univentricular and biventricular defects (Figure 4).

Plasma cGMP is released in response to stimulation of membrane-bound natriuretic peptide receptors. Therefore, plasma cGMP may be considered as a crude surrogate 


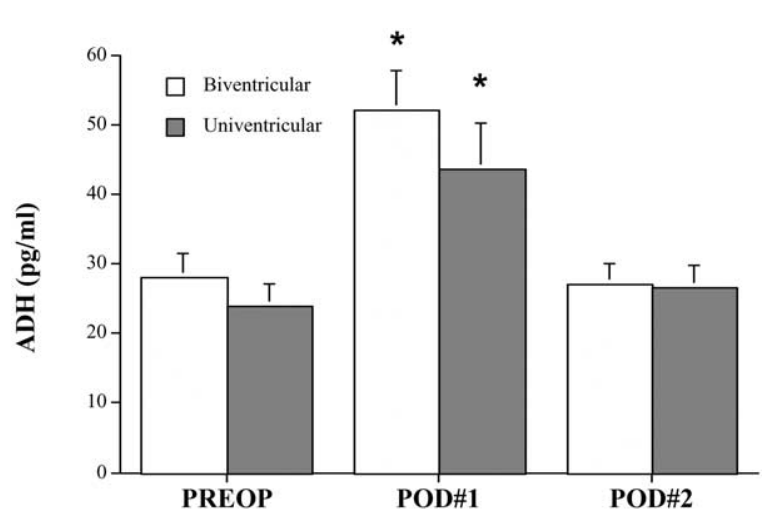

Figure 4. Biventricular and univentricular patients showed similar patterns of plasma ADH during the perioperative period. Both groups had a significant increase in plasma ADH on postoperative day (POD) 1 that returned to preoperative values by POD 2. *P $<.05$ versus before surgery (PREOP).

marker for natriuretic peptide function. We examined the correlation of molar concentrations of cGMP and plasma natriuretic peptide to evaluate receptor/cGMP coupling. There was a significant correlation between preoperative plasma cGMP and plasma ANP in the biventricular group $(r$ $=0.42 ; P=.04)$, but not in the univentricular group $(r=$ $0.19 ; P=.33$ ). Similarly, a significant correlation was found between plasma BNP and cGMP in patients with biventricular defects $(r=0.44 ; P=.02$; Figure 5$)$, but not in those with univentricular defects $(r=0.13 ; P=.51$; Figure 6). Therefore, there seemed to be an uncoupling of preoperative natriuretic peptides from the intracellular cGMP signaling pathway. Moreover, in both groups of patients, there was no clear relationship between either ANP or BNP and plasma cGMP after surgery, thus suggesting that the coupling of the natriuretic peptide receptors to their signaling cascades was disrupted during the immediate postoperative period.

\section{Discussion}

The main findings of this study were that patients with univentricular cardiac defects showed evidence of dysfunction of the BNP system in 2 ways. First, their baseline plasma ANP and BNP were less well correlated with plasma cGMP compared with those with biventricular defects. This is consistent with the idea that natriuretic peptide receptors are less well coupled to the intracellular signaling pathway in these patients. Second, plasma BNP in the univentricular group remained unchanged after surgery, whereas plasma BNP in those with biventricular defects increased significantly.

Increased plasma ANP and BNP are reported in patients with a variety of cardiac diseases. , $^{5,8,31-33}$ Specifically, patients with congenital cardiac defects show an increase in

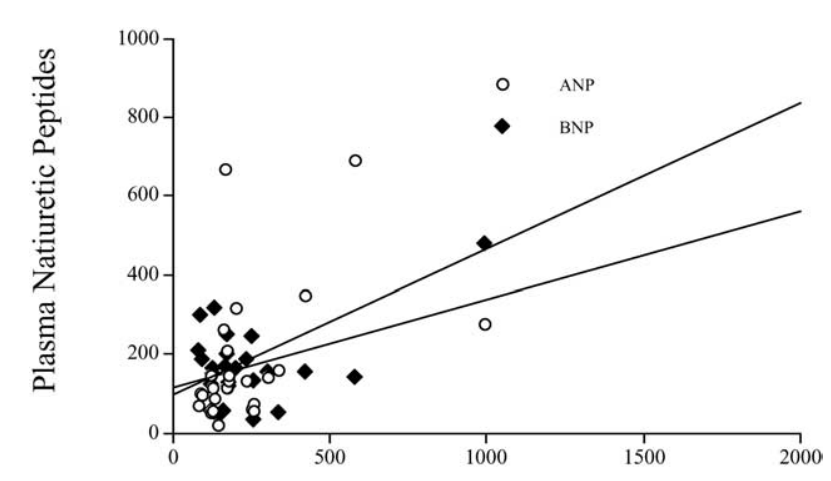

Plasma cGMP

Figure 5. Preoperative plasma cGMP significantly correlated with plasma ANP and plasma BNP in patients with biventricular defects $(P<.05)$.

plasma ANP and BNP. ${ }^{7,8,34}$ We found plasma ANP and BNP in both groups of patients to be similar to values that have been reported in the literature for patients with congenital cardiac disease. ${ }^{7,35}$ It has also been noted that there is often a greater increase in plasma BNP than in ANP (in molar concentrations) in cardiac patients. ${ }^{26}$ In contrast to noncardiac patients whose plasma ANP is much higher than plasma BNP, plasma BNP often approaches or is higher than plasma ANP in cardiac patients. ${ }^{25,36}$ Consistent with these earlier reports, we found that both the univentricular and biventricular groups had comparable plasma ANP and BNP. More recently, plasma ANP and BNP have been used as biomarkers of cardiac dysfunction in clinical cardiac medicine. Plasma BNP is now used as a diagnostic tool and is used as a marker for the prognosis and evaluation of therapy in adults with heart failure. ${ }^{5,21,37,38}$ The recombinant human BNP is now available for therapeutic use in the

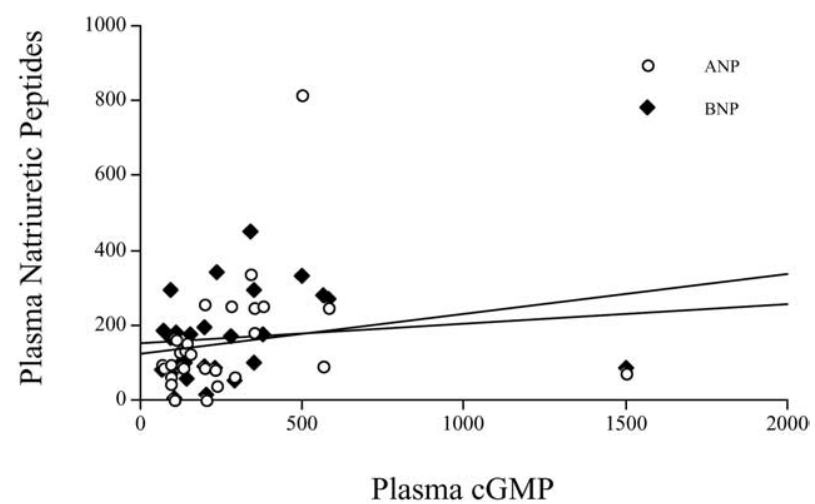

Figure 6. Preoperative plasma cGMP did not correlate with either plasma ANP or plasma BNP in patients with univentricular defects. 
treatment of compensated heart failure because of its documented beneficial effect to improve cardiac function independently of its diuretic effect. ${ }^{38}$

ANP and BNP are both important in the maintenance of volume homeostasis through inducing natriuresis, diuresis, and vasodilation. ${ }^{1,3,39}$ They also act to inhibit the reninangiotensin-aldosterone axis. Another important role played by the natriuretic peptides is the regulation of cardiac growth during development. ${ }^{2}$ This is underscored by the finding that mice that are genetically engineered to be devoid of natriuretic peptide receptors have increased heart weights and increased cardiac expression of both ANP and BNP. $^{2}$ The actions of ANP and BNP to inhibit vascular smooth muscle cell proliferation, to suppress cardiac fibroblast growth, and to inhibit cardiomyocyte hypertrophy have been well documented. ${ }^{2}$

Univentricular defects are associated with hypoplastic development of one of the ventricles. Because ANP and $\mathrm{BNP}$ are hormones that are both produced in the ventricles during embryonic development, we hypothesized that hypoplasia of the ventricle and maldevelopment of the ventricles could lead to a disruption in the ontogeny of the ANP and BNP system.

Both ANP and BNP bind to cell-surface natriuretic peptide receptors to stimulate the membrane-bound guanylyl cyclase and to generate the second-messenger cGMP to exert its biological action. ${ }^{4,39,40}$ Plasma cGMP, the second messenger of natriuretic peptide action, has also been shown to be increased in children with cardiac disease. ${ }^{25,41}$ Cyclic GMP can be generated via stimulation of particulate or cytosolic guanylyl cyclase. Natriuretic peptides are the only known endogenous ligands that simulate the particulate form of the guanylyl cyclase enzyme, whereas nitric oxide stimulates the cytosolic form of the guanylyl cyclase enzyme. ${ }^{42,43}$ Because of the intracellular location of the cytosolic guanylyl cyclase enzyme, plasma cGMP reflects the cellular production of cGMP by the particulate form of the guanylyl cyclase enzyme in response to natriuretic peptide stimulation. The correlation between plasma natriuretic peptides and cGMP could thus be used as a crude estimate of the coupling of the natriuretic peptide receptors to their intracellular signaling pathway. ${ }^{25,44}$ Our results indicate that although the increase of plasma ANP, BNP, and cGMP was comparable in the univentricular and biventricular groups, only in the biventricular group was there a significant linear correlation between plasma ANP or BNP and plasma cGMP. In contrast, plasma ANP or BNP was poorly correlated with plasma cGMP in the univentricular group.

Although we clearly documented that there was a difference in natriuretic peptides between the univentricular and biventricular groups, our results by no means establish a cause and effect relationship between hypoplastic ventricu- lar development and abnormal natriuretic peptide function. However, the clear difference between the univentricular and biventricular groups in the postoperative change in plasma BNP is consistent with our hypothesis that ventricular hypoplasia induces a disruption in the ontogeny of the natriuretic peptide system.

It was entirely predictable that there would be a postoperative increase in BNP, as was the case with the biventricular patients, because increases in plasma BNP have been clearly documented after cardiopulmonary bypass in adults. However, there was no such increase in plasma BNP during the postoperative period in patients with univentricular defects. Studies examining fluid-regulating hormones in Fontan and Glenn patients have documented increased plasma ADH and aldosterone during the postoperative period. ${ }^{13,19,27,45}$ Furthermore, the increase in ADH has been correlated with the development of fluid-retentive states clinically. ${ }^{19,20}$ In this study, we found plasma ADH to be increased in both groups of patients during the postoperative period. However, the response in BNP and aldosterone was significantly different between the 2 study groups. In the patients with biventricular defects, there was a significant postoperative increase in BNP, but not aldosterone. In contrast, in the patients with univentricular defects, there was a significant increase in plasma aldosterone, but not BNP. Because BNP is known to inhibit the secretion of aldosterone, the absence of the inhibitory influence of BNP may account for the significant postoperative increase in aldosterone in the univentricular group.

Persistent postoperative fluid retention, pleural effusion, pericardial effusion, and ascites frequently complicate the postoperative course of patients who undergo the Fontan procedure. ${ }^{19,46,47}$ Although we did not specifically document the fluid status of our patients after surgery, the persistent increase in ADH and aldosterone with a concomitant absent natriuretic peptide response in the univentricular group might predispose these patients toward a greater tendency for fluid retention. Our results suggest that the complications related to fluid retention after univentricular repair, which have been often attributed to the surgical procedures, may in fact be due to an inherent defect or dysfunction of the natriuretic peptide system in patients with congenital univentricular defects who undergo those procedures.

Because we demonstrated that plasma cGMP did not correlate with plasma natriuretic peptides in univentricular patients, our results suggest that the natriuretic receptor/ effector uncoupling may represent an inherent defect in the function of the natriuretic peptide system in these patients. Consequently, one might further speculate that the therapeutic actions of exogenously administered BNP could be attenuated in this group of patients. Future studies specifically detailing the response to recombinant BNP in this 
population will shed light on this issue. Our results indicate that there was a significant increase in plasma aldosterone during the postoperative period; this may be a secondary effect of the abnormal natriuretic response. This suggests that there might be a role for aldosterone antagonists in the management of postoperative fluid retention in this patient population.

\section{References}

1. Baxter GF. The natriuretic peptides. Basic Res Cardiol. 2004;99:71-5.

2. Cameron VA, Ellmers LJ. Minireview: natriuretic peptides during development of the fetal heart and circulation. Endocrinology. 2003; 144:2191-4.

3. Dhingra H, Roongsritong C, Kurtzman NA. Brain natriuretic peptide: role in cardiovascular and volume homeostasis. Semin Nephrol. 2002; 22:423-37.

4. Forssmann WG, Richter R, Meyer M. The endocrine heart and natriuretic peptides: histochemistry, cell biology, and functional aspects of the renal urodilatin system. Histochem Cell Biol. 1998;110:335-57.

5. de Lemos JA, McGuire DK, Drazner MH. B-type natriuretic peptide in cardiovascular disease. Lancet. 2003;362:316-22.

6. Matsuoka S, Kurahashi Y, Tomimatsu H, Miyao M, Yamazaki Y, Nishiuchi T, et al. Plasma atrial natriuretic peptide levels in patients with ventricular septal defect. J Pediatr. 1987;110:578-80.

7. Matsuoka S, Kurahashi Y, Miki Y, Miyao M, Yamazaki Y, Nishiuchi $\mathrm{T}$, et al. Plasma atrial natriuretic peptide in patients with congenital heart diseases. Pediatrics. 1988;82:639-43.

8. Ross RD, Daniels SR, Dolan LM, Young CA, Meyer RA. Determinants of plasma atrial natriuretic factor concentrations in congenital heart disease. Am J Cardiol. 1988;62(10 Pt 1):785-8.

9. Agnoletti G, Scotti C, Panzali AF, Ceconi C, Curello S, Alfieri O, et al. Plasma levels of atrial natriuretic factor (ANF) and urinary excretion of ANF, arginine vasopressin and catecholamines in children with congenital heart disease: effect of cardiac surgery. Eur J Cardiothorac Surg. 1993;7:533-9.

10. Ationu A, et al. Studies of cardiopulmonary bypass in children: implications for the regulation of brain natriuretic peptide. Cardiovasc Res. 1993;27:1538-41.

11. Avidan MS, Singer DR, Smith A, Elliott M, Burch M, Carter ND. Changes in brain natriuretic peptide concentrations following open cardiac surgery with cardioplegic cardiac arrest. Clin Chim Acta. 2001;303:127-32.

12. Berendes E, Schmidt C, Van Aken H, Hartlage MG, Rothenburger M, Wirtz S, et al. A-type and B-type natriuretic peptides in cardiac surgical procedures. Anesth Analg. 2004;98:11-9.

13. Burch M, Shinebourne EA, Rigby ML, Carter N, Jeffery S, Stanley P, et al. Plasma atrial natriuretic peptide after the Fontan procedure and total cavopulmonary connexion. Int J Cardiol. 1990;27:161-5.

14. Hjortdal VE, Stenbog EV, Ravn HB, Emmertsen K, Jensen KT, Pedersen EB, et al. Neurohormonal activation late after cavopulmonary connection. Heart. 2000;83:439-43.

15. Tweddell JS, Litwin SB, Thomas JP Jr, Mussatto K. Recent advances in the surgical management of the single ventricle pediatric patient. Pediatr Clin North Am. 1999;46:465-80, xii.

16. Fontan F, Baudet E. Surgical repair of tricuspid atresia. Thorax. 1971;26:240-8.

17. Mainwaring RD, Lamberti JJ, Uzark K. The bidirectional Glenn procedure: palliation of the univentricular heart. Adv Card Surg. 1994;5: $115-40$.

18. Bridges ND, Jonas RA, Mayer JE, Flanagan MF, Keane JF, Castaneda AR. Bidirectional cavopulmonary anastomosis as interim palliation for high-risk Fontan candidates. Early results. Circulation. 1990;82(5 suppl):IV170-6.

19. Stewart JM, Gewitz MH, Clark BJ, Seligman KP, Romano A, Zeballos $\mathrm{GA}$, et al. The role of vasopressin and atrial natriuretic factor in postoperative fluid retention after the Fontan procedure. $J$ Thorac Cardiovasc Surg. 1991;102:821-9.
20. Mainwaring RD, Lamberti JJ, Carter TL Jr, Moore JW, Nelson JC. Renin, angiotensin II, and the development of effusions following bidirectional Glenn and Fontan procedures. J Card Surg. 1995;10: 111-8.

21. Bhatia V, Nayyar P, Dhindsa S. Brain natriuretic peptide in diagnosis and treatment of heart failure. J Postgrad Med. 2003;49:182-5.

22. Cardarelli R, Lumicao TG Jr. B-type natriuretic peptide: a review of its diagnostic, prognostic, and therapeutic monitoring value in heart failure for primary care physicians. J Am Board Fam Pract. 2003;16:327-33.

23. Hoffman A, Grossman E, Keiser HR. Increased plasma levels and blunted effects of brain natriuretic peptide in rats with congestive heart failure. Am J Hypertens. 1991;4(7 Pt 1):597-601.

24. Wei CM, Heublein DM, Perrella MA, Lerman A, Rodeheffer RJ, McGregor CG, et al. Natriuretic peptide system in human heart failure. Circulation. 1993;88:1004-9.

25. Hayabuchi Y, Matsuoka S, Kuroda Y. Plasma concentrations of atrial and brain natriuretic peptides and cyclic guanosine monophosphate in response to dobutamine infusion in patients with surgically repaired tetralogy of fallot. Pediatr Cardiol. 1999;20:343-50.

26. Bolger AP, Sharma R, Li W, Leenarts M, Kalra PR, Kemp M, Coats AJ, et al. Neurohormonal activation and the chronic heart failure syndrome in adults with congenital heart disease. Circulation. 2002; 106:92-9.

27. Mainwaring RD, Lamberti JJ, Moore JW, Billman GF, Nelson JC. Comparison of the hormonal response after bidirectional Glenn and Fontan procedures. Ann Thorac Surg. 1994;57:59-63; discussion 64.

28. Pfenninger J, Shaw S, Ferrari P, Weidmann P. Atrial natriuretic factor after cardiac surgery with cardiopulmonary bypass in children. Crit Care Med. 1991;19:1497-502.

29. Ationu A, Carter ND. Brain and atrial natriuretic peptide plasma concentrations in normal healthy children. Br J Biomed Sci. 1993;50: 92-5.

30. Haug C, Metzele A, Kochs M, Hombach V, Grunert A. Plasma brain natriuretic peptide and atrial natriuretic peptide concentrations correlate with left ventricular end-diastolic pressure. Clin Cardiol. 1993; 16:553-7.

31. Brookes CI, Kemp MW, Hooper J, Oldershaw PJ, Moat NE. Plasma brain natriuretic peptide concentrations in patients with chronic mitral regurgitation. J Heart Valve Dis. 1997;6:608-12.

32. Goetze JP, Christoffersen C, Perko M, Arendrup H, Rehfeld JF, Kastrup J, et al. Increased cardiac BNP expression associated with myocardial ischemia. FASEB J. 2003;17:1105-7.

33. Naruse M, Takeyama Y, Tanabe A, Hiroshige J, Naruse K, Yoshimoto $\mathrm{T}$, et al. Atrial and brain natriuretic peptides in cardiovascular diseases. Hypertension. 1994;23(1 suppl):I231-4.

34. Costello JM, Backer CL, Checchia PA, Mavroudis C, Seipelt RG, Goodman DM. Alterations in the natriuretic hormone system related to cardiopulmonary bypass in infants with congestive heart failure. Pediatr Cardiol. 2004;25:347-53.

35. Oberhansli I, Mermillod B, Favre H, Friedli B, Girardin E, Paunier L. Atrial natriuretic factor in patients with congenital heart disease: correlation with hemodynamic variables. J Am Coll Cardiol. 1990;15: 1438-45.

36. Dzimiri N, Moorji A, Afrane B, Al-Halees Z. Differential regulation of atrial and brain natriuretic peptides and its implications for the management of left ventricular volume overload. Eur J Clin Invest. 2002; 32:563-9.

37. Moazami N, Damiano RJ, Bailey MS, Hess RL, Lawton JS, Moon MR, et al. Nesiritide (BNP) in the management of postoperative cardiac patients. Ann Thorac Surg. 2003;75:1974-6.

38. Fonarow GC. B-type natriuretic peptide: spectrum of application. Nesiritide (recombinant BNP) for heart failure. Heart Fail Rev. 2003; 8:321-5.

39. de Bold AJ, Ma KK, Zhang Y, de Bold ML, Bensimon M, Khoshbaten A. The physiological and pathophysiological modulation of the endocrine function of the heart. Can J Physiol Pharmacol. 2001;79:705-14.

40. Bonow RO. New insights into the cardiac natriuretic peptides. Circulation. 1996;93:1946-50.

41. Nakaoka H, Imataka K, Kitahara Y, Fujii J, Ishibashi M, Yamaji T. Relationship between plasma levels of atrial natriuretic peptide and 
cyclic guanosine monophosphate in patients with heart diseases. Jpn Circ J. 1988;52:30-4.

42. Chinkers M, Garbers DL, Chang MS, Lowe DG, Chin HM, Goeddel $\mathrm{DV}$, et al. A membrane form of guanylate cyclase is an atrial natriuretic peptide receptor. Nature. 1989;338:78-83.

43. Chinkers M, Garbers DL. Signal transduction by guanylyl cyclases. Annu Rev Biochem. 1991;60:553-75.

44. Fujio N, Ohashi M, Nawata H, Kato K, Ibayashi H, Matsuo H. Relationship between atrial natriuretic polypeptide and cyclic $3{ }^{\prime} 5^{\prime}-$ guanosine monophosphate in human plasma. J Lab Clin Med. 1987;109:706-10.

45. Stewart JM, Seligman KP, Zeballos G, Romano A, Clarke BJ, Woolf $\mathrm{PK}$, et al. Elevated atrial natriuretic peptide after the Fontan procedure. Circulation. 1987;76(3 Pt 2):III77-82.

46. Jacobs ML, Pourmoghadam KK. The hemi-Fontan operation. Semin Thorac Cardiovasc Surg Pediatr Card Surg Anпи. 2003;6:90-7.

47. Marino BS. Outcomes after the Fontan procedure. Curr Opin Pediatr. 2002;14:620-6.

\section{The Thoracic Surgery Foundation for Research and Education}

The Thoracic Surgery Foundation for Research and Education (TSFRE) was founded to provide its four sponsoring societies with a dedicated and common organization for research and education activities within cardiothoracic surgery. The TSFRE has developed a variety of distinctive, cutting-edge research endeavors, including clinical research partnerships with the National Heart, Lung, and Blood Institute and the National Cancer Institute. These partnerships will lead to significant progress in our specialty. In developing these research programs, TSFRE provides surgeons with dynamic opportunities to extend themselves while benefiting cardiothoracic surgery and our patients. Research leads to discovery, new techniques and procedures, and ultimately to dramatic advances to pressing medical and surgical problems.Recognizing that both education and research create the future of cardiothoracic surgery, the TSFRE has also developed an exciting new education initiative. Based on the TSFRE Education Committee's extensive analysis of future needs of cardiothoracic surgeons, TSFRE is creating three education programs that will support funding of projects in the acquisition of transdisciplinary skills, patient safety, and simulation training for cardiothoracic surgeons. We are currently reaching out to industry and major philanthropic organizations to establish funding for these forward looking programs.As the onset of the income tax season often leads to consideration of various options for the use of one's funds, TSFRE asks you to make an annual donation to the Foundation or, if you are already a donor, to increase the level of your gift. Tax-deductible gifts and pledges that sum to $\$ 10,000$ will make you a Life Member of TSFRE. Annual gifts can include securities that have appreciated in value, thereby providing you with additional tax relief.TSFRE especially asks you to use this time to reflect on building your legacy within the specialty. Please consider, as an acknowledgment of what cardiothoracic surgery has done for you, by making a planned gift to TSFRE. Planned giving offers a donor many ways in which to make a sizeable donation without a cash outlay. The most common planned gift is a charitable bequest to TSFRE through your will after you have properly insured that your family and other loved ones will be financially secure. Real estate as a planned gift can be a very practical mechanism. A donor may even give real estate and yet retain the use of the property. Other forms of planned giving include life insurance and charitable remainder trusts. You might consider establishing a charitable trust in the name of your family. Once you have made the basic decision that you would like to support research and education in cardiothoracic surgery, please visit our Web site (www.tsfre.org) and make a donation online. In considering a planned gift and the options available to you, we urge you to consult with your financial advisor. TSFRE would also be happy to discuss these and other planned gift options with you. Please feel free to contact Joe Webber, the Director of Development, at 978-927-8330 or e-mail him at jwebber@prri.com. 